\title{
KONSTELASI KURIKULUM PENDIDIKAN DI INDONESIA
}

\author{
RUSTAM ABONG \\ rustamabong@yahoo.com.sg \\ adalah Dosen Jurusan PAI FTIK IAIN Pontianak
}

\begin{abstract}
Curriculum in Indonesia is always related to the constellation of power, and therefore the direction and substance of the curriculum are determined by the decision of state authorities and non-state subsystems, or complying to a certain notion and concept of education. Constellation of power and complexity of curriculum can be seen in the instruction of Competency-Based Curriculum (KBK), school-based curriculum (KTSP) and 2013 Curriculum. After all, there is no guarantee that these curriculums will be able to develop students' competency and build their character in line with the national education goals as mandated by Law No. 20/2003 on National Education System. In fact, there is nothing wrong with the curriculum; it is the fault of policy makers of education. The Indonesian people need political will of the government. Curriculum is not the only factor that determines the quality of education. Nor is it the only tool to realize the vision of education. However, curriculum can serve as a strategic device to seed the interests of power. Changes in curriculum in fact generate a strong constellation of power in the curriculum itself, especially in determining the content of education, so no wonder education in Indonesia is "subjugated" by curriculums with business and political interests.
\end{abstract}

Keywords: curriculum, education, constellation of power, competency-based curriculum, school-based curriculum \& 2013 curriculum

\section{LATAR BELAKANG}

Satu diantara organ pendidikan ialah kurikulum. Kurikulum merupakan aspek penting dalam pendidikan, yang seringkali bergonta-ganti sesuai keinginan pemegang kekuasaan. Kita sering mendengar adagium "ganti menteri ganti kurikulum". Ini menandakan bahwa, kurikulum sebagai bagian dari penentu keberhasilan untuk mencapai tujuan pendidikan nasional belum dibuat dan dirumuskan sebagai isu bersama untuk pengembangan pendidikan di Indonesia. Harusnya, pengembangan kurikulum menjadi isu bersama dan dilakukan oleh semua stakeholder pendidikan di negara ini, kalau mau membentuk manusia Indonesia yang seutuhnya, dibangun berdasarkan karakter bangsa Indonesia yang tertuang dalam Undang-Undang Nomor 20 Tahun 2003 tentang Sistem Pendidikan Nasional, yaitu "Berkembangnya potensi peserta didik agar menjadi manusia yang beriman dan bertakwa kepada Tuhan Yang Maha Esa, berakhlak mulia, sehat, berilmu, cakap, kreatif, mandiri, dan menjadi warga negara yang demokratis serta bertanggungjawab”.

Pergantian kurikulum pendidikan di Indonesia seringkali dikritik oleh para pelaku pendidikan. Kritikan mereka tujukan pada 
argumen yang mendasari perumusan dan pemberlakuan kurikulum. Kurikulum sebenarnya bukan satu-satunya penentu untuk meningkatkan mutu pendidikan. Tetapi fungsi kurikulum dalam dunia pendidikan dan pembelajaran akan dapat mengangkat mutu dan kualitas peserta didik apabila didukung kecakapan para pendidik (guru atau dosen), ketercakupan substansi kurikulum dalam buku ajar, tersedianya sarana dan prasarana belajar dan kepemimpinan pendidikan dalam mengimplementasikan kurikulum tersebut.

Dewasa ini, kurikulum menjadi perangkat atau dokumen yang bersifat umum untuk diketahui, sehingga akan strategis dimanfaatkan untuk beberapa kepentingan atau konstelasi Pemerintah dalam membentuk konsepsi dan perilaku pedagogis peserta didik menjadi tidak seimbang. Kurikulum yang dirancang dan diinginkan selama ini oleh pemerintah masih belum menekankan sepenuhnya kemandirian dan perkembangan multidimensi peserta didik. Mestinya perkembangan pribadi peserta didik dalam merancang kurikulum akan menjadi capaian tujuan dalam pendidikan dan pembelajaran.

Pergantian kurikulum pendidikan di Indonesia selalu berhubungan dengan kekuasaan dan perangkat lainnya menjadi konstelasi atau ajang pengaruh kekuasaan. Sehingga arah dan substansi kurikulum hanya ditentukan oleh keputusan-keputusan pemegang kekuasaan negara maupun subsistem non negaranya, atau menurut aliran kepentingannya dalam bidang pendidikan. Akhirnya kajian atas kurikulum lambat laun akan menjadi jenuh serta kehilangan relevansi untuk meningkatkan kualitas dan mutu pendidikan. Sebagaimana yang diungkapkan oleh Yusran Pora (2007: 24) bahwa kurikulum sekolah sekarang ini merupakan bentuk pemaksaan dan penekanan yang benar-benar mengerikan bila dibandingkan dengan bentuk-bentuk pemaksaan dan penekanan lainnya. Bagaimana tidak menekan dan memaksa bila kurikulum tersebut hanya "menuntut" dan mengharuskan peserta didik untuk melakukan "ini" dan "itu". Ini semua karena memang muatan kurikulum tersebut masih banyak konstelasi kekuasaan ketika merancangnya.

Bagaimana sesungguhnya konstelasi kekuasaan dalam kurikulum dari pergantian kurikulum 1975 kemudian berganti menjadi kurikulum tahun 1984, berganti lagi menjadi kurikulum tahun 1994, kemudian kurikulum tahun 2000, tahun 2004 dan kurikulum tahun 2006 atau KTSP, serta Kurikulum 2013 yang berlaku hingga sekarang, akan menjadi pembahasan dan analisis dalam tulisan ini. Pentingnya membahas dan menganalisis permasalahan ini adalah agar pembaca mengetahui sebenarnya bahwa merancang kurikulum sangat kompleks dan penuh dengan kepentingan kelembagaan maupun individual dan kelompok.

Sebagai akademisi, penulis mencoba meninjau ulang dan menelusuri pergantian kurikulum dari tahun ke tahun secara teoritis dan praktis, apakah penuh dengan kepentingan konstelasi kekuasaan? atau apakah pergantian kurikulum itu sebenarnya hanya kebijakan yang dibuat penguasa untuk mencari popularitas? dan apakah dengan pergantian kurikulum itu akan berpengaruh mengangkat mutu serta kualitas pendidikan? Pertanyaan-pertanyaan tersebut akan dijawab dalam tulisan ini.

\section{KURIKULUM DAN KONSTELASI KEKUASAAN}

Secara historis, otokritik ini berawal dari Kurikulum 1975, Kurikulum 1984, dan Kurikulum 1994 yang dikritik karena memberikan terlalu banyak mata pelajaran, materi 
yang terlalu padat, dan membuat proses belajar mengajar, buku teks, dan Evaluasi Belajar Tahap Akhir Nasional (EBTANAS) atau sekarang dikenal dengan nama Ujian Nasional (UN) menjadi seragam. Kemudian semakin menjadi kompleks lagi diadakan kurikulum suplemen tahun 2000, kemudian diberlakukannya Kurikulum Berbasis Kompetensi (KBK) tahun 2004. Lebih kompleks lagi pada tahun 2006, KBK dirubah menjadi Kurikulum Tingkat Satuan Pendidikan (KTSP) tahun 2008 sampailah sekarang KTSP dan Kurikulum 2013 diberlakukan secara bersamaan, tergantung kesiapan satuan pendidikan masing-masing yang berlaku secara nasional.

Belum genap sepuluh tahun, kurikulum 1975 sudah diubah lagi ketika Menteri Pendidikan dan Kebudayaan dijabat oleh Nugroho Notosusanto dikenal dengan Kurikulum 1984. Adapun hal yang menonjol dari Kurikulum 1984 adalah dimasukkannya pelajaran Pendidikan Sejarah Perjungan Bangsa (PSPB) sebagai pelajaran wajib dari sejak Sekolah Dasar (SD) sampai dengan Sekolah Menengah Atas (SMA/SMK/MA). Ide dasar yang diinginkan pemerintah (penguasa) memasukkan mata pelajaran PSPB adalah agar murid mengenal sejarah bangsanya sendiri dengan lebih baik dan siswa dapat mengambil pelajaran dari peristiwa sejarah. Oleh karena itu, pelajaran sejarah pada waktu itu tidak hanya dihafal, melainkan dibuat menarik agar tumbuh semangat kebangsaan pada peserta didik. Tetapi materi PSPB belum lama diluncurkan sudah menimbulkan kontroversi karena dinilai tumpang tindih dengan pelajaran Ilmu Pengetahuan Sosial (IPS), Sejarah Nasional, dan Pendidikan Moral Pancasila (PMP) yang kesemuanya bicara tentang sejarah nasional Indonesia.

Bandingkan perbedaannya dengan Kurikulum 1984 yang proses pemunculannya amat cepat, langsung diganti dengan Kurikulum 1994 yang dipersiapkan cukup lama karena dimulai oleh Menteri Pendidikan dan Kebudayaan Fuad Hassan. Asumsinya, Kurikulum 1994 akan jauh lebih baik dari Kurikulum 1984. Hal yang menonjol dari Kurikulum 1994 ini adalah dominasi mata pelajaran matematika serta bahasa (Indonesia dan Inggris) dalam seluruh jenjang pendidikan. Tetapi Kurikulum 1994 juga menuai kritik yang disebabkan minimnya pelajaran seni, baik seni rupa, seni suara, seni musik, seni karya dan seni-seni lainnya. Sebagaimana yang dikatakan oleh Darmaningtyas (2004: 81) bahwa Kurikulum 1994 sebagai proses pemiskinan cita rasa seni kita sebagai manusia karena manusia direduksi hanya untuk menguasai teknologi saja". ${ }^{1}$

Kurikulum 1994 dalam prosesnya tidak lepas juga dari konstelasi penguasa (pemerintah), seperti mata pelajaran Pendidikan Moral Pancasila (PMP) dirubah menjadi Pendidikan Pancasila dan Kewarganegaraan. Dalam kurikulum ini unsur pendidikan kewarganegaraan mulai dimasukkan. Materi PSPB yang dalam Kurikulum 1984 menjadi jam tersendiri, resmi dihapuskan. Begitu juga dengan penjurusan SMA diubah lagi, didasarkan pada nilai akhir kelas II atau dinilai pada saat naik kelas III dan jenis penjurusannya dikembalikan seperti semula, yaitu Jurusan IPA, IPS, Agama dan Bahasa dan

1 Para penyusun kurikulum tampaknya lupa bahwa teknologi hanya dapat berkembang dengan baik bila muncul kreativitas dan inovasi di masyarakat. Sedangkan kreativitas dan inovasi itu terbangun dan dapat tumbuh, salah satunya melalui seni budaya. Kehidupan manusia tanpa seni juga menjadikan manusia sangat steril sehingga selalu merasa terasing dari alam keramaiannya, merasa ada sesuatu yang hilang dari hidupnya. Tetapi sayang, apreasi seni tidak memperoleh tempat dalam lembaga pendidikan formal terutama yang termuat dalam Kurikulum 1994. 
tidak lagi menggunakan sistem kredit seperti Kurikulum 1984. Lebih parah lagi pada masa Menteri Pendidikan Wardiman Djojonegoro mengubah semester menjadi caturwulan dan mengganti sebutan SMP menjadi SLTP, SMU menjadi SMA dan SMK (Sekolah Menengah Kejuruan).

Perkembangan Kurikulum 1994 dalam prosesnya diperkenankannya konsep Kurikulum Muatan Lokal (Mulok), yang sebelumnya memang tidak dikenal. Mulok ini merupakan jam atau dapat disebut "area abu-abu" (gray area) yang dapat direbutkan oleh siapapun untuk diberi makna sesuai dengan kepentingan dan keperluannya. Mulok cukup banyak berkembang di sekolah atau madrasah, sehingga semua diharapkan dapat menutup kekurangan materi pelajaran lain yang belum diatur dalam kurikulum nasional. Secara konseptual, ide Mulok itu bagus, karena dimaksudkan untuk mengakomodasi potensi-potensi lokal yang tidak mungkin terwadahi dalam kurikulum nasional. Tetapi pada tingkat implementasinya, mata pelajaran Mulok itu tersentral pada tingkat Provinsi, artinya jenis mata pelajaran Mulok dalam satu Provinsi itu sama. Pada umumnya jenis mata pelajaran Mulok yang diberikan adalah Bahasa Daerah, Kesenian, Olahraga dan atau Keterampilan. Hal ini juga tidak lepas dari konstelasi kekuasaan birokrasi dalam menjalankan kurikulum.

Nampaknya memang kalau mengacu pada Foucault (dalam Y. Dedy Pradipto, 2007:16) bahwa kekuasaan merupakan strategi yang kompleks dalam suatu masyarakat dengan mekanisme tertentu. Dengan demikian sebenarnya dapat dipahami negara tidak memiliki kekuasaan. Sebetulnya kekuasaan bekerja pada negara, dan kurikulum nasional dapat dilihat sebagai salah satu wujudnya. Sistem yang rumit dari kekuasaan tersebut disebut sebagai konstelasi kekuasaan. Dunia pendidikan sekarang berada dalam konstelasi kekuasaan dimana kurikulum dapat dilihat sebagai wujud dari sistem tersebut. Bagaimana dengan KBK dan KTSP apakah termasuk perwujudan dari sistem rumit tersebut? Apakah KBK dan KTSP yang menggunakan kompetensi dapat membangun karakter peserta didik?.

Kurikulum Berbasis Kompetensi (KBK) yang kemudian dikenal dengan Kurikulum 2004, merupakan suatu model kurikulum yang berlaku di Indonesia sebagai konsekuensi diberlakukannya peraturan perundang-undangan tentang desentralisasi yang mengatur pemerintah pusat dan daerah. Wina Sanjaya (2005:8) mengatakan bahwa, pemberlakuan KBK adalah suatu bentuk inovasi kurikulum. Juga kemunculan KBK seiring dengan munculnya semangat reformasi pendidikan. Diawali dengan munculnya kebijakan pemerintah diantaranya lahirnya Undang-Undang Nomor 22 tahun 1999 tentang Pemerintahan Daerah, Undang-Undang Nomor 25 tahun 2000 tentang Kewenangan Pemerintah dan Kewenangan Provinsi sebagai Daerah Otonomi serta lahirnya Tap. MPR No. IV/MPR/1999 tentang Arah Kebijakan Pendidikan di Masa Depan.

Sebenarnya sejak tahun 2000 pemerintah telah mengeluarkan draft KBK. Pada intinya bahwa KBK menggantikan Kurikulum 1994, yang mana lebih menekankan pada keleluasaan dalam aktivitas belajar mengajar. Peserta didik menjadi pusat perhatian dalam proses belajar mengajar, kemampuan anak menjadi pertimbangan pertama guru untuk melakukan sesuatu di kelas. Relasi yang terjadi dalam aktivitas belajar mengajar pada KBK adalah dialogis antara guru dan murid, relasi ini dimungkinkan juga dengan metode diskusi dan dimungkinkan adanya kesempa- 
tan bagi murid untuk aktif bertanya dan memberikan informasi. Guru lebih berperan sebagai pendamping, fasilitator dan rekan yang mengajak murid untuk melakukan eksplorasi belajar.

Diberitakan surat kabar Kedaulatan Rakyat, 16 Mei 2006 yang dikutip oleh M. Joko Susilo (2007: 25) bahwa KBK adalah kurikulum pendidikan yang berubah-ubah dan jadi "kebingungan" tersendiri bagi pendidik maupun peserta didik. Dengan KBK peserta didik seakan-akan menjadi kelinci percobaan Pemerintah untuk menemukan kurikulum mana pengaruhnya lebih besar terhadap mutu pendidikan. Jadi tidak heran jika Pemerintah melakukan kebijakan belum genap satu tahun kurikulum, sudah diusulkan untuk diganti dengan kurikulum yang lain. Akan lebih parah lagi pergantian kurikulum tersebut diikuti dengan pergantian buku dan ini menjadi ladang bisnis pihak-pihak tertentu untuk memperkaya diri, dimana peserta didik diwajibkan untuk membeli buku tersebut.

M. Joko Susilo (2007: 25) mengatakan KBK adalah "kurikulum berbasis kebingungan", mungkin itu lebih tepat untuk mengistilahkan kurikulum pendidikan tersebut yang selalu gonta ganti. KBK tidak terlalu lama pemberlakuannya dan belum sepenuhnya diterapkan di sekolah-sekolah terutama di daerah-daerah pedalaman, perbatasan, dan pantai, bahkan ada sekolah yang belum sempat dilaksanakan sosialisasi tentang KBK, kemudian oleh Pemerintah diganti lagi dengan Kurikulum Tingkat Satuan Pendidikan (KTSP).

Kurikulum KTSP sebenarnya sudah terendus dalam Undang-Undang Nomor 20 Tahun 2003 tentang Sistem Pendidikan Nasional, pada Pasal 36 Ayat 2. Juga apa yang disebut KBK, yang diluncurkan dua tahun sebelum KTSP, secara eksplisit telah diamanatkan pada bagian penjelasan umum Undang-Undang Nomor 20 Tahun 2003. Jadi sebenarnya baik KTSP maupun KBK diamanatkan oleh produk hukum yang sama. Persoalannya adalah mungkinkah suatu butir ketentuan hukum dalam sebuah produk hukum menghasilkan butir ketentuan lain dalam pruduk hukum yang sama?. Lagi pula kalau dicermati tampak bahwa KTSP mengatur distribusi kewenangan dalam pembelajaran terutama dalam hal strategi, metode pembelajaran kepada sekolah dan guru. Sedangkan KBK adalah memandu arah pembelajaran dalam kelas. Dengan demikian KBK dan KTSP sebenarnya saling melengkapi.

KBK dan KTSP juga sama-sama menekankan pentingnya partisipasi kreatif guru dan proses belajar yang berpusat pada siswa (student centered learning). Guru ditantang menciptakan suasana belajar yang kontekstual dengan lingkungan keseharian peserta didik. Demikian juga pembelajaran menekankan suasana yang menyenangkan. Proses pembelajaran harus interaktif, menantang dan memotivasi peserta didik, memberi ruang prakarsa, kreativitas, dan kemandirian sesuai dengan bakat, minat, fisik dan perkembangan psikologis peserta didik.

Meskipun demikian kedua kurikulum ini pada saat diluncurkan memiliki kesamaan persoalan, yakni ketika KBK diluncurkan kesiapan guru diragukan, hal yang sama juga pada KTSP. Memang pada kenyataannya sepanjang pengetahuan penulis ketika menanyakan persoalan ini dengan guru-guru, ternyata masih banyak guru yang bingung harus berbuat apa saat KTSP diterapkan. Teorinya memang mudah, tetapi praktiknya sulit. KTSP banyak dipandang membingungkan guru. Bagaimana tidak bingung, pembelajaran dan penyusunannya dituntut kreatif dari sekolah dan guru, sementara penilaian- 
nya tetap menggunakan penilaian hasil dan menggunakan Ujian Nasional sebagai standar kelulusan. Inilah masalah-masalah teknis yang dihadapi praktisi pendidikan di lapangan ketika pemberlakuan kurikulum.

Sebagai ikhtiar penyempurnaan kurikulum, Menteri Pendidikan dan Kebudayaan Muhammad Nuh kemudian meluncurkan kurikulum baru pengganti KTSP yakni Kurikulum 2013. Mindset Kurikulum 2013 adalah menyiapkan generasi emas Indonesia yang memiliki karakter kebangsaan yang kuat, memiliki daya saing yang sejajar dengan negara-negara maju lainnya seperti Amerika Serikat, Tiongkok, Finlandia, dan Singapura. Tetapi apa dikata, tidak lebih dari satu tahun, muncul kebijakan baru dari Menteri Pendidikan dan Kebudayaan yang baru yaitu Anies Baswedan dengan menerbitkan Surat Edaran Mendikbud. Nomor 179342/MPK/KR/2014 tentang Pelaksanaan Kurikulum 2013, yang intinya menyatakan kurikulum yang dipakai ialah KTSP dan bagi lembaga pendidikan yang sudah atau masih mau menggunakan Kurikulum 2013 silakan dilanjutkan. Ini tentu saja lebih membingungkan para guru, apalagi bagi peserta didik.

Sebenarnya kita tidak bisa menafikan bahwa sebelum sebuah kurikulum diimplementasikan dan disosialisasikan serta diberlakukan di sekolah atau madrasah, telah mengandung banyak sumbangan pemikiran dari para stakeholder pendidikan, ide para pakar, bahkan penelitian, dan uji publik. Ada yang mengusulkan kurikulum berbasis karakter, kurikulum berbasis alam, kurikulum berbasis tauhid, dan masih banyak lagi kurikulum lainnya dan disesuaikan dengan "selera". Pertanyaannya adalah kurikulum mana yang tepat diantara kurikulum yang telah diberlakukan tersebut di atas untuk pendidikan kita?. Sebenarnya tidak ada yang salah den- gan kurikulum, yang salah adalah pelaku pendidikan yang tidak konsisten dalam membuat kebijakan pendidikan, banyak konstelasi politik dan kepentingan dalam kurikulum.

Memang bagaimanapun tidak bisa dielakkan, dalam pendidikan pasti ada muatan politis dalam semua aktivitasnya, sebagaimana yang dungkapkan oleh M. Agus Nuryatno (2008: 2) dalam buku Mazhab Pendidikan Kritis $^{2}$ dikatakan bahwa pendidikan tidak bisa dipisahkan dari konteks sosial, kultural, ekonomi dan politik yang lebih luas. Institusi pendidikan tidaklah netral, independen, dan bebas dari berbagai kepentingan, tetapi justru menjadi bagian dari institusi sosial lain yang menjadi ajang beberapa kepentingan.

\section{KURIKULUM DAN REDUKSI MAKNA PENDIDIKAN}

Pendidikan merupakan suatu proses untuk memungkinkan peserta didik mengembangkan seluruh potensi yang dimiliki secara optimal agar yang bersangkutan dapat menjalani kehidupan dengan efektif dan efesien, sehingga keberadaannya tidak saja berguna bagi diri pribadi tetapi bermanfaat juga bagi keluarga, masyarakat dan bangsanya. Dengan pengertian tersebut di atas pendidikan merupakan suatu proses yang hidup dan menghidupkan seluruh komponen pendidikan yang ada, khususnya guru dan peserta didik. Namun sejauh ini pendidikan hanya diperlaku-

2 Pendidikan kritis (critical pedagogy) adalah mazhab pendidikan yang meyakini adanya muatan politik dalam semua aktifitas pendidikan. Mazhab ini dalam diskrusus pendidikan disebut juga "aliran kiri”, karena orientasi politik pendidikannya berlawanan dengan mazhab liberal dan konservatif. Diantara tokoh mazhab pendidikan kritis ini seperti Henry Giroux (1993), Paula Allman (1998), Peter McLaren (1998) mereka menyebut mazhab pendidikan kritis adalah pendidikan radikal (radical education), pendidikan revolusioner (revolutionary pedagogy). 
kan sebagai proses transfer of knowledge, dan transfer of value masih sebatas retorika, dan ini semua karena diantara penyebabnya adalah kurikulum yang selalu berubah-ubah, sehingga substansi pendidikan sedikit demi sedikit terhimpit oleh kurikulum.

Konteks saat ini, kemunculan KTSP sebagai sebuah kurikulum menjadi sangat krusial dalam pengembangan pendidikan di Indonesia. Dulu KBK diharapkan akan meningkatkan mutu pendidikan, akan tetapi kenyataannya tidak demikian. Beberapa persoalan justru muncul ketika diberlakukannya KBK atau pada saat itu disebut kurikulum 2004. Diantara persoalan tersebut adalah ketuntasan dalam pembelajaran, masing-masing sekolah berbeda dalam menentukan ketuntasan belajar. Begitu juga dengan remedial teaching, kebanyakan pembelajaran yang dilakukan guru kurang dan belum tuntas. Bagi anak yang belum tuntas tersebut harus diberikan remedial atau perbaikan supaya mereka dapat mengikuti materi selanjutnya, tetapi guru enggan untuk melakukannya karena pelaksanaan remedial itu kebanyakan tidak dibayar, padahal dilakukan diluar jam pelajaran.

Faktor penyebab tidak optimalnya KBK menurut M. Joko Susilo (2007: 67-68) ada tiga hal:

"Pertama, inkonsistensi aplikasi menyebabkan amburadulnya pelaksanaan pendidikan di Indonesia. Kedua, ada perbedaan interpretasi dan implementasi KBK ditingkat penatar, kepala sekolah, dan para guru karena sosialisasi belum optimal. Ketiga, kemunculan KBK yang berpijak pada asumsi bahwa kondisi sekolah di Indonesia tidak sama, seharusnya menjadi kerangka dasar bagi pemerintah dalam menerapkannya".
Ketika KBK diberlakukan, orang beranggapan bahwa kurikulum ini dapat meningkatkan kompetensi siswa, akan tercipta sumberdaya manusia yang memiliki pengetahuan serta keterampilan hidup. Tetapi setelah dilihat materi pelajaran yang begitu padat, sedangkan waktu yang tersedia sangat terbatas. Guru juga dalam menerapkan KBK asal-asalan saja, padahal guru harus melaksanakan yang prinsip yaitu menggunakan strategi mastery learning (belajar tuntas) dalam pembelajaran KBK. Hal yang sama juga sebenarnya KBK itu diterjemahkan sebagai wewenang penuh oleh sekolah, namun pemerintah masih turut mencampuri wewenang sekolah dalam pemberlakuan KBK, contoh Ujian Nasional (UN) masih bersifat sentralistik. Dimana standar kelulusan dan soal-soal ujian ditentukan oleh pusat. Jelas ini bertentangan dengan prinsip KBK, seharusnya itu semua ditetapkan oleh pendidik dan sekolah.

Menurut Agus Suwignyo yang dikutip oleh A. Ferry T. Indratno (Forum Mangunwijaya, 2008: 107) dalam tulisannya "Kurikulum Beridentitas Kerakyatan" mengatakan bahwa, "kurikulum memang bukan satu-satunya penentu mutu pendidikan. Kurikulum juga bukan perangkat tunggal penjabaran visi pendidikan, meskipun demikian kurikulum menjadi perangkat yang strategis untuk menyemaikan kepentingan dan membentuk konsepsi dan perilaku individu warga".

Memang kalau dilihat dalam sejarah pendidikan di Indonesia, pergantian kurikulum sudah beberapa kali. Pada masa Orde Lama saja pernah tiga kali pergantian kurikulum, yaitu Kurikulum 1947, Kurikulum 1952, dan Kurikulum 1964. Sedangkam pada masa Orde Baru kurikulum dimulai dari Kurikulum 1975. Kemudian berubah menjadi Kurikulum 1984, yang pada saat 
itu diterapkanlah pendekatan Cara Belajar Siswa Aktif (CBSA). Setelah itu muncul lagi Kurikulum 1994, kurikulum ini menjadi kurikulum terakhir yang dikeluarkan pada masa Orde Baru. Pada masa Reformasi tahun 2000 dimunculkan lagi apa yang disebut "Suplemen Kurikulum” atau Kurikulum 2000 yang disosialisasikan adalah Kurikulum Berbasis Kompetensi (KBK). Baru pada tahun 2004 resmi ditetapkan sebagai kurikulum yang diberlakukan untuk pendidikan diseluruh Indonesia yang disebut Kurikulum 2004 atau KBK. Tahun 2006 kurikulum berubah lagi dari KBK menjadi KTSP sebagai penyempurnaan dari kurikulum KBK. Tahun 2013 kurikulum berubah lagi dari KTSP menjadi Kurikulum 2013. Terakhir pada 2014 kurikulum diberlakukan dua jenis yaitu Kurikulum 2013 dan kembali kepada KTSP. Tentu saja kebijakan tersebut menunjukkan kebimbangan pemerintah sehingga pendidikan semakin terhimpit oleh kurikulum yang sarat kepentingan kekuasaan.

Kalau diperhatikan, perubahan kurikulum dari periode Orde Lama ke periode Orde Baru dan dari Orde Baru kepada zaman "Reformasi", betapa sesungguhnya konstelasi kekuasan dalam kurikulum sangat kuat dalam penentuan isi pendidikan, sehingga pendidikan di Indonesia menjadi "terhimpit" oleh kurikulum. Benar apa yang dikatakan oleh Pierre Bourdieu yang dikutip oleh A. Ferry T. Indratno (Forum Mangunwijaya, 2008: 108) bahwa "setiap tindakan pedagogis yang bertujuan untuk mereproduksi kebudayaan dapat disebut kekerasan simbolis yang sah. Kekuatan kekerasan ini berasal dari hubungan kekuasaan sesungguhnya yang disembunyikan oleh kekuatan pedagogis". Kurikulum yang berlaku dalam suatu negara, termasuk Indonesia sering digunakan sebagai sarana indoktrinasi dari suatu sistem kekua- saan. Terkadang para pendidik dan apalagi masyarakat luas kurang menyadari apa sebenarnya peranan kurikulum di dalam proses pendidikan dan pembelajaran.

Orang sering menganggap persoalan kurikulum adalah persoalan teknis saja dalam pendidikan, padahal sebenarnya kalau berbicara tentang kurikulum maka akan bicara tentang masa depan anak bangsa, bukan hanya untuk kepentingan kekuasaan semata. Karena didalam kurikulum tersebut berbicara tentang program mengenai tujuan, isi, strategi, dan evaluasi dalam sistem pendidikan. Kemudian bagaimana didalam kurikulum mencoba untuk melaksanakan proses akumulasi ilmu pengetahuan bagi peserta didik pada setiap tingkatan. Oleh karena itu sebaiknya kurikulum yang dirancang secara nasional hendaknya dihindari kepentingan-kepentingan kekuasaan, apalagi bermotif ekonomi dan bisnis. Tetapi betul-betul dirumuskan sesuai dengan kebutuhan pengembangan pendidikan di Indonesia, sehingga pendidikan tidak "terhimpit" oleh kurikulum dan dengan demikian diharapkan pendidikan dapat membentuk manusia Indonesia yang seutuhnya atau "Insan Kamil" dalam tujuan pendidikan Islam.

\section{PENUTUP}

Konstelasi kekuasaan dalam perumusan kurikulum pendidikan memang realita yang tidak terbantahkan. Hal ini sah-sah saja terjadi, asalkan dimaksudkan untuk meningkatkan mutu pendidikan bagi bangsa Indonesia. Memang, pada zaman modern, perkembangan pengetahuan dan kebutuhan kompetensi bidang kerja mau tidak mau menuntut penyesuaian kurikulum pendidikan oleh pemerintah, dalam hal ini Kementerian Pendidikan dan Kebudayaan. Tetapi perubahan kurikulum hendaknya dilakukan secara 
sistematis, terencana, terukur, dan bertujuan untuk mencapai tujuan pendidikan nasional. Perubahan kurikulum bukan dilakukan karena kepentingan kekuasaan sesaat, kepentingan kelompok, apalagi ada motif bisnis.

Indonesia memerlukan orang-orang yang secara ikhlas bekerja memajukan bangsa Indonesia. Kepentingan kekuasaan sesaat, kepentingan kelompok, apalagi ada motif bisnis harus dihilangkan dalam pikiran para penguasa di negeri ini. Kalaupun perlu dilakukan perubahan kurikulum, hendaknya dikaji dulu secara mendalam, sehingga tidak terkesan perubahan kurikulum dipaksakan. Stakeholder pendidikan selain pemerintah harus dilibatkan, antara lain seperti para pakar pendidikan, perguruan tinggi, organisasi kemasyarakatan, PGRI, dan aktivis pendidikan. Jika ini dilakukan, maka yakinlah bahwa pendidikan di Indonesia akan maju dan produknya siap berkompetisi dengan negara lain di dunia.

\section{DAFTAR PUSTAKA}

Beauchamp, George A. 1978. Curriculum Teory. Willmette Illionis: The KAGG Press.

Darmaningtyas. 2004. Pendidikan yang Memiskinkan. Yogyakarta: Galang Press.

Depdiknas. 2000. Kurikulum Berbasis Kompetensi. Jakarta: Pusat Kurikulum Balitbang Depdiknas.

Forum Mangunwijaya. 2008. Kurikulum yang Mencerdaskan Visi 2030 dan Pendidikan Alternatif. Jakarta: Kompas Penerbit Buku.

Idi, Abdullah. 1999. Pengembangan
Kurikulum, Teori dan Praktek. Jakarta: Gaya Media Pertama.

Indratno, A. Ferry T. 2013. Perspektif Pendidikan Humanis

Mangunwijaya: Kurikulum 2013. Jakarta: Kompas Media Nusantara.

James, Beane A. 1995. Toward A Coharent Curriculum. Alexandria, Virginia: ASCD.

Kemendikbud. 2013. Pengembangan Kurikulum 2013. Di http: //www. kemdiknas.go.id/ kemdikbud/ujipublik-kurikulum-2013.html.

2014. Surat Edaran Nomor: 179342/MPK/KR/2014 tanggal

5 Desember 2014 tentang Pelaksanaan Kurikulum 2013.

Ketetapan MPR No. IV/MPR/1999 tentang Arah Kebijakan Pendidikan di Masa Depan.

Kurniasih, Imas dan Sani, Berlin. 2014. Sukses Mengimplementasikan Kurikulum 2013, Memahami Berbagai Aspek Dalam Kurikulum 2013. Yogyakarta: Kata Pena.

Mac Donald, James B. 1978. Educational Models for Instruction. Washington DC: The Association for Supervesion and Curriculum Deveploment.

Mastuhu. 2003. Menata Ulang Pemikiran Sistem Pendidikan Nasional dalam Abad 21. Yogyakarta: Safiria Insania Press.

Mauritz, Johnson. 1977. Intetionality in Education. New York: Center 
for Curriculum Research and Services.

Muhaimin, dkk. 2008. Pengembangan Model Kurikulum Tingkat Satuan Pendidikan (KTSP) Pada Sekolah dan Madrasah. Jakarta: PT. Raja Grapindo Persada.

Mulyasa, E. 2003. Kurikulum Berbasis Kompetensi:

Konsep,

Karakteristik, dan Implementasi. Bandung: Remaja Rosdakarya.

Nasution, S. 1997.Pengembangan Kurikulum. Bandung: Citra Aditya Bakti.

Nizar, Samsul, (Ed). 2002. Filsafat Pendidikan Islam: Pendekatan Historis, Teoritis dan Praktis. Jakarta: Ciputat Press.

Notoseputro, Naba Aji. 2008. The Spirit of Change: Mengubah Paradigma Sistem Pendidikan dan Pembelajaran di Indonesia. Jakarta: Teraju (PT. Mizan Publika).

Nurhayati, Tuti Kurnia. 2005. Kamus Lengkap Bahasa Indonesia Dengan Ejaan Yang Disempurnakan. Jakarta: Etika Muda Press.

Nuryatno, M. Agus. 2008. Mazhab Pendidikan Kritis Menyingkap Relasi Pengetahuan Politik dan Kekuasaan. Yogyakarta: Resist Book.

Pora, Yusran. 2007. Selamat Tinggal Sekolah. Yogyakarta: MedPress.

Rohman, Muhammad. 2012. Kurikulum Berkarakter (Refleksi dan Proposal Solusi Terhadap KBK dan KTSP). Jakarta: Prestasi
Pustaka.

Rowntree. 1998. Teaching Thinking Accros the Curriculum. New York: Harpe \& Row, Publisher.

Sanjaya, Wina. 2005. Pembelajaran dalam Implementasi Kurikulum Berbasis Kompetensi. Jakarta: Prenada Media.

Shaleh, Abdul Rahman. 2005. Pendidikan Agama dan Pembangunan Watak Bangsa. Jakarta: Raja Grafindo Persada.

Soetopo. H.S dan Soemanto W. 1993. Pembinaan dan pengembangan kurikulum: Sebagai Substansi Problem Administrasi Pendidikan. Jakarta: Bumi Aksara.

Subandjijah. 1996. Pengembangan dan Inovasi Kurikulum. Jakarta: Raja Grafindo Persada.

Sudjana, Nana. 1991. Pembinaan dan Pengembangan Kurikulum di Sekolah. Bandung: Sinar Baru.

Sukmadinata, Nana Syaodih. 1997. Pengembangan Teori Kurikulum dan Praktik. Bandung: Remaja Rosdakarya.

1998. Prinsip dan Landasan Pengembangan Kurikulum. Jakarta: P2LPTK Depdikbud.

Susilo, M. Joko. 2007. Pembodohan Siswa Tersistematis. Jakarta: Perpustakaan Nasional.

Taba, Hilda. 1962. Curriculum Development: Theory and Practices. New York: 
Harcourt, Brace and World. Inc.

Thok, Fatur. 2013. "Perbedaan Kurikulum 2013 dan KTSP". Di https: // fatkoer.wordpress.com.

Tilaar, H.A.R. 1994. Manajemen Pendidikan Nasional: Kajian Pendidikan Masa Depan. Bandung: Remaja Rosdakarya.

Undang-Undang Republik Indonesia Nomor 22 tahun 1999 tentang Pemerintahan Daerah.

Undang-Undang Republik Indonesia Nomor 25 tahun 2000 tentang Kewenangan Pemerintah dan Kewenangan Provinsi sebagai Daerah Otonomi.

Undang-Undang Republik Indonesia Nomor 20 Tahun 2003 tentang Sistem Pendidikan Nasional.

Yani, Ahmad. 2014. Mindset Kurikulum 2013. Bandung: Alfabeta.

Zais, Robert S. 1976. Curriculum Principles and Foundationns. New York: Harper \& Row Publisher.

Zein, Muhammad. 1991. Asas dan Pengembangan Kurikulum. Yogyakarta: Sumbangsih Offset. 